\title{
Dual Partisanship in the South: Anachronism, or a Real Barrier to Republican Success in the Region?
}

Jay Barth, University of North Carolina, Chapel Hill

This paper employs contemporary polling data to determine the degree to which dual partisanship is preponderant in the mass public of the eleven southern states. Because dual partisanship shows a lack of connection between the national political parties and the parties at lower levels, widespread dual partisanship could be seen as an important barrier to the "trickling down" of Republicanism in the region. While dual partisanship is not found to be present in large numbers in the contemporary southern electorate, differences in the partisan commitments of southem voting groups -- of age, gender, and subregion -- have important implications for the present and future workings of southern voting groups -- of age, gender, and subregion -- have important implications for the present and future workings of sourthem politics. The paper goes on to discuss how this absence of dual partisanship from the thinking of most members of the mass electorate in the region could coexist with evidence of dual partisanship among southem party activists reported in recent survey results.

Political shifts that qualify for the categorization of "critical elections," i.e. those political alterations that "represent a break in electoral continuity" (Pomper $1967,561)$, normally begin at the highest levels and then "trickle down" to affect races for lower level offices. The major critical elections theorists -- including Sundquist (1983), Key (1959), and Burnham (1970) -- all see this "trickling down" of presidential voting trends to voting for lower offices at the federal, state, and local levels as inevitable. Over time, voters will come to "square" their voting tendencies at the presidential level with those for such lesser positions.

For such a "squaring" of votes to occur, however, it seems logical that a relatively strong connection between the national parties and the parties at lower levels must exist in the minds of voters. Using survey data from the 1982 Louisiana state Democratic convention and the state's 1983 Republican convention, Charles Hadley (1985) has found evidence that such a linkage may not exist for many southerners. Not only did the party activists that Hadley surveyed perceive vital differences in the national and state parties, but a significant number of them even admitted voting for different parties' candidates at the two levels. Citing 1968 Comparative State Elections Project (CSEP) surveys, Hadley suggested that comparable levels of dual partisanship existed among voters in Louisiana and even higher levels could be found in the rest of the South. The finding contrasted with Philip E. Converse's (1966) earlier dismissal of southern dual partisanship as a salient political factor, based on the 1958 SRC American National Election Survey. While Hadley's evidence for dual partisanship among southern elites was 
fairly contemporary, his tool for tapping dual partisanship in the mass public -- the CSEP -- was significantly older, and also problematic because of the "Wallace factor" in southern politics in that tumultuous year.

Other party identification surveys of the mass electorate in particular southern states during recent years also have indicated that different levels of support for the two parties could be found. For instance, a Fall, 1985 Alabama state poll showed 28 percent of Alabamians identifying themselves as Republicans at the national level, while only 18 percent onsidered themselves Republicans in state and local politics (Thomas and Stewart 1988, 123). ${ }^{1}$

While much has changed in the region's politics, the Republican party's influence below the presidential level in the South remains inconsistent. Stanley (1988) notes that while Southern white Republican party identifiers are more loyal to their presidential candidates than are white Democratic partisans, these Democratic partisans are consistently more loyal than are Republicans in voting for the U.S. Senate, U.S. House of Representatives, and governor. However, it is in "down-ticket" elections, races for statewide elected offices below the gubernatorial level which are most removed from the national political tides, that the elusiveness of top-to-bottom electoral success in the South is most starkly shown (Sturrock 1990; Barth and Haskell 1990). At this level of southern politics, things do not look all that different from the days of the Solid South. For instance, during the 1980s, state Republican parties fielded candidates for "down-ticket" offices only about half the time, winning only 2.7 percent of the races $(n=184){ }^{2}$

It is important, therefore, to determine the degree to which dual partisanship, one potential hindrance to top-to-bottom realignment in the South, predominates in the mass public of the eleven southern states. The Spring 1992, Southern Focus poll conducted by the Institute for Research in Social Science at the University of North Carolina at Chapel Hill offered a unique opportunity to gauge the level of dual partisanship that persists in the southern mass public. ${ }^{3}$ Four questions that essentially replicated the dual partisanship questions on the 1968 Comparative State Election Project (CSEP) Mass Survey were used to examine the consistency of party identification at the two distinct levels of politics. ${ }^{4}$ These questions were asked of 656 adults residing in the eleven states of the Confederacy. The poll's margin of error was approximately 3.5 percent.

This paper will report the findings of this examination of dual partisanship in the contemporary South. Has dual partisanship decreased or increased in the southern electorate since the 1968 CSEP Mass Survey? Do the levels of consistency in partisanship at the two levels differ among important subgroups of the southern electorate, i.e. by subregion, by gender, and (most significant for the future of southern politics) by age? And, most importantly, are there enough dual partisans in the southern mass electorate to serve as a real barrier to Republican success below the presidential level, or do structural barriers such as differences in party organization effectiveness and candidate quality stand in the way of 
consistent Republican "top-to-bottom" competitiveness in the region?

\section{Dual Partisanship at the Mass Level in 1992}

As Hadley reported, an important chunk of voters in the South in 1968 who identified themselves as Democrats at the state level did not identify with the party at the national level. The levels of dual partisanship in the mass public in the region in 1968 (excluding Wallace respondents, as well as those voters who did not identify with any party), as found in the CSEP mass survey, are shown in Table $1 .{ }^{5}$ A voter is categorized as a "consistent" partisan if s/he has exactly the same degree of party or independent identification at the two levels, a "partially consistent" partisan if $s /$ he has the same basic identification with a variance in strength of identification at the two levels, and a "split" partisan if the respondent's national party identification differs from his/her basic state party attachment. For example, if a voter identifies with the Democratic party (either strongly or weakly) at the state level, but considers him/herself and Independent in national politics, the respondent is categorized as a "split Democrat."

Table 1. Dual Partisan Identification in 5 Southern States, Comparative State Election Project (CSEP) Mass Survey, 1968*

Consistent Republican

$11.3 \%$

Partially Consistent Republican

1.6

Splis Republican

4.9

Consistent Independent

9.8

Partially Consistent Independent

4.1

Split Independent

1.5

Consistent Democrat

43.1

Partially Consistent Democrat

9.6

Split Democrat

14.1

Weighted $N=1833$

$100.0 \%$

*This table is adapted from Hadley (1985). Wallace identifiers and nonpartisans are eliminated from the original data.

The figures indicate that about two-thirds (64.2 percent) of the 1968 respondents were completely consistent in their party identifications at the two levels, and only another 16.3 percent -- mostly partially consistent Democrats -- fit into one of the three "partially consistent" categories. Fully 20.5 percent of the sample fit into one of the three "split" categories. And, indicative of a more firm loyalty to their state Democratic parties than to the national Democratic party of John Kennedy and Lyndon Johnson, most of these (14.1 percent) were "split Democrats."

With the dramatic shifts that occurred in southern voting patterns in the 
nearly quarter century since the CSEP survey, one would expect movement away from the Democratic party in both state and national identifications to be evident in the 1992 survey results. However, the tremendous regional success of Republican presidential candidates during the 1980s accompanied by continued Democratic dominance down the ticket might suggest that the movement away from the Democratic party at the state level may not have occurred at the same rate, i.e., the levels of dual partisanship in the region actually might be higher than in 1968. If this were found to be the case, dual partisanship in the mass electorate could be seen as an important factor in the inconsistency of Republican success below the presidential level in the South.

The results from the Southern Focus Poll, however, show that the party identification of southerners in state and in national politics are very similar. These 1992 results are shown in Table 2 . There is essentially no difference in the per-

Table 2. National and State Party Identification in the 11 Southern States, Spring 1992 Southern Exposure Poll*

\begin{tabular}{lcc}
\hline & National & State \\
\hline Strong Democrat & $16.9 \%$ & $16.8 \%$ \\
Not Very Strong Democrat & 18.6 & 18.8 \\
Independent, Closer to Democrat & 9.5 & 10.2 \\
Independent & 9.3 & 8.8 \\
Independent, Closer to GOP & 11.1 & 13.3 \\
Not Very Strong GOP & 18.5 & 17.2 \\
Strong Republican & 16.5 & 14.9 \\
& & $100.0 \%$ \\
$\mathrm{n}=656$ & $100.0 \%$ & \\
\hline
\end{tabular}

*Those respondents who identified with another party were not included.

centage of Democratic identifiers at the two levels -- 35.5 percent of southerners consider themselves Democrats at the national level; 35.6 percent at the state level. There is a little more variation in the Independent and Republican identifications. While 32.3 percent of southerners place themselves in one of the three Independent categories when it comes to politics in their states, slightly fewer (29.9 percent) consider themselves independents in national politics. The converse is true in terms of Republican identification: 35.0 percent of voters are Republicans in national politics; 32.2 percent put themselves in either the strong or weak Republican categories in state politics.

\section{The Increased Consistency of Individual Southern Voters}

Clearly, this consistency in mass level partisanship at the two levels could mask a good deal of variation in the identifications of individuals at the two levels. 
To better measure the presence of dual partisanship in the contemporary southern electorate, it is necessary to return to the measures of individual consistency implemented by Hadley. These results are shown in Table 3 .

Table 3. Dual Partisan Identification in the 11 Southern States, Spring 1992 Southern Exposure Poll

Consistent Republican

$26.1 \%$

Partially Consistens Republican

2.3

Split Republican

3.8

Consistent Independent

19.4

Partially Consistent Independent

3.4

Split Independent

9.6

Consistent Democrat

29.0

Partially Consistent Democrat

2.0

Split Democrat

$\underline{4.6}$

$100.0 \%$

$\mathrm{n}=656$

The numbers differ from the 1968 mass survey results in several important ways. First, and least surprising, is the sharp increase in the percentage of consistent Republican and Independent identifiers during the last quarter century. More than one-fourth of southerners (26.1 percent) are now consistent Republican identifiers, while just over one-tenth of southerners identified with the Republican party with the same intensity at the two levels in 1968. And, consistent Independent identifiers have nearly doubled over the period; 19.4 percent of southern voters now fit in this category. The notable decline during the period, of course, was in the percentage of consistent Democrats, who dropped from 43.1 percent in 1968 to 29.0 percent in 1992 -- a percentage only slightly more numerous than consistent Republicans in the region. Such findings restate the degree to which the southern electorate has shifted during the past generation, with neither party nowhere near a majority in the South.

Even more important, however, for students of dual partisanship is the major decline in the percentage of "split Democrats." While 14.1 percent of southerners in 1968 identified with the Democratic party at the state level but had a different basic identification in national politics, only 4.6 percent of the 1992 sample are "split Democrats." The movement away from the Democratic party by these voters, evidently a two-step process in which the initial loss of faith in the national Democratic party is followed by a consonant disaffection with the state party, apparently has reached a point of equilibrium. There was nearly a 10 percentage point gap in the levels of "split Democrats" and "split Republicans" in 1968. Now, the percentage of "split Democrats" is only slightly larger than the percentage of "split Republicans" (3.8 percent).

Also, the increase in independent identification has been accompanied $g$ by a sharp increase in the percentage of "split Independents," with 9.6 percent of southerners now fitting in this category. If this "split Independent" group were 
overwhelmingly Republican in their national party identification, this category might be seen as analogous to the sharp increase in white southern Independent identification in the late 1960s, when independence was characterized as "a halfway house to the Republican party" (Schreiber 1971, 161). But, even with this group, there is surprising balance in the manner in which this group "splits" when it comes to national politics: 58.8 percent identify themselves as Republicans; 41.2 percent as Democrats.

Overall, 74.5 percent of southerners in 1992 are consistent in their party identifications at the national and state levels. An additional 7.7 percent are partially consistent in their identifications (i.e., their identifications at the national and state levels do not differ if only the three-point partisan scale is used). This is a picture of a dramatically altered, but much stabler electorate than the southern voters of a quarter century ago.

\section{A Look at Important Subgroups}

While the increased consistency of the southern electorate as a whole is an important finding, it also is necessary to examine certain important subgroups of the mass electorate to determine if the consistency found in it varies by age, by gender, or by subregion in the South.

Age

It is clear from numerous pieces of evidence that younger southerners have been less hesitant than their parents and grandparents to identify with the Republican party. Therefore, with an eye on the future of southern politics at the state level, it is useful to determine if younger southern voters are distinctive in their partisan attachments at the two levels. The survey results, when broken down into four age groups, show that while that expected correlation between age and strength of attachment to the Democratic Party exists, there is little variation across age groups in the consistency of identifications at the two levels (see Table 4). For the youngest group of voters, 18 to 29 year olds, 75.6 percent of the respondents are consistent in their partisan identifications, with a strong plurality ( 30.9 percent) of them consistent Republicans. It is interesting to note that, unlike the other age groups, slightly more "split Republicans" (i.e., those less likely to identify with the national Republican party) than "split Democrats" are found in this group.

For the next age group, 30 to 44 year olds, about the same percentage of respondents ( 74.5 percent) fit into one of the three consistent categories. This group is more evenly balanced among the three identifications. Again, for the 45 to 64 year old group, 75.0 percent are consistent identifiers, with consistent Democrats in the plurality. Finally, for those over 65 years, 71.4 percent are consistent identifiers, over half of whom are Democrats. With this group, some faint vestiges of dual partisanship may exist. Although the numbers are small, 
twice as many of this group are "split Democrats" (5.6 percent) than are "split Republicans" (2.8 percent).

Table 4. Dual Partisan Identification in the 11 Southern States, by Age, Spring 1992 Southern Exposure Poll

\begin{tabular}{lcccc}
\hline & \multicolumn{4}{c}{ Years } \\
\cline { 2 - 5 } & $18-29$ & $30-44$ & $45-64$ & $65+$ \\
\hline & $30.9 \%$ & $26.8 \%$ & $25.5 \%$ & $19.5 \%$ \\
Consistent Gop & 2.4 & 2.1 & 1.6 & 3.7 \\
Partially Consistent GOP & 6.5 & 3.4 & 3.2 & 2.8 \\
Split Republicans & 25.2 & 20.9 & 17.0 & 13.9 \\
Consistent Independents & 4.1 & 1.9 & 3.2 & 5.6 \\
Partially Consistent Independents & 4.9 & 11.1 & 11.7 & 8.5 \\
Split Independents & 19.5 & 26.8 & 32.5 & 38.0 \\
Consistent Democrats & 1.6 & 2.6 & 1.1 & 2.5 \\
Partially Consistent Democrats & 4.9 & 3.9 & $\underline{4.3}$ & 5.6 \\
Split Democrats & $100.0 \%$ & $100.0 \%$ & $100.0 \%$ & $100.0 \%$ \\
& $(\mathrm{n}=123)$ & $(\mathrm{n}=235)$ & $(\mathrm{n}=188)$ & $(\mathrm{n}=108)$ \\
& & & & \\
\hline
\end{tabular}

The distinctly different balances of consistent party identifications in the four age groups presents a stark picture of the generational nature of the shifts that have taken place in the southern electorate. Both "consistent Republicans" and "consistent Independents" steadily decline in percentage across the age breaks, while the percentage of "consistent Democrats" steadily increases. In fact, the percentage of "consistent Democrats" in the youngest age group is equivalent to the percentage of "consistent Republicans" in the oldest group.

And, while the balance of identifications varies across age groups, the consistency of identifications at the state and national levels does not vary. The Republican Party, at both the national and state levels, seems to have a great opportunity ahead of it among the southern voters with the most voting years left in them. However, the exit poll results from the 1992 presidential politics indicate that this group of voters is a volatile one in all regions of the country (New York Times 5 November 1992). With the increased consistency of partisanship in the region, this opportunity for future success at all levels in the South for the GOP could fall apart because of national Republican party failures.

\section{Gender}

In their examination of contemporary presidential politics in the region, Black and Black argue that "gender may be the demographic key to improved Democratic fortunes" $(1992,362)$. The findings of the Southern Exposure poll indicate that this strategy very well may apply to state politics in the South, as 
well. Levels of dual partisanship, broken down by gender, are shown in Table 5 .

Table 5. Dual Partisan Identification in the 11 Southern States, by Sex,

Spring 1992 Southern Exposure Poll

\begin{tabular}{lcc}
\hline & Male & Female \\
\hline Consistent GOP & $26.6 \%$ & $25.5 \%$ \\
Partially Consistent GOP & 1.8 & 2.7 \\
Split Republicans & 3.4 & 4.3 \\
Consistent Independents & 21.7 & 16.9 \\
Partially Consistent Independents & 4.9 & 1.8 \\
Split Independents & 9.8 & 9.4 \\
Consistent Democrats & 24.8 & 33.1 \\
Partially Consistent Democrats & 1.5 & 2.4 \\
Split Democrats & 5.5 & 3.6 \\
& $100.0 \%$ & $100.0 \%$ \\
& & $(\mathrm{n}=327)$ \\
\hline
\end{tabular}

Southern women are slightly more consistent in their partisanship. However, the more significant finding is that while the amount of consistent support at the two levels for the Republican party is about the same for both sexes, a prominent gap exists between women and men in support for the Democratic Party at the two levels. About one-third of southern women (33.1 percent) are consistent Democrats, while less than one-fourth of men ( 24.8 percent) fit in this category. And, interestingly, while southern men are more likely to be "split Democrats" than "split Republicans," a slightly larger percentage of women are more loyal to the state Republican Party than to the national party. The national Democratic party "turns off" southern men, but southern women are more likely to have problems with the national Republican party.

Therefore, these numbers reinforce Black and Black's argument that there is an opportunity for Democrats, at both levels, to peel off a significant chunk of white voters by making appeals to women through the use of economic and social issues and through the presentation of candidates that have legitimacy in representing the unique interests of women.

\section{Subregions}

The distinctiveness of two southern subregions, the Deep South and the Peripheral South, based on political history and demographics, has been clearly shown (Black and Black 1987). ${ }^{7}$ Therefore, it might be expected that differing levels of dual partisanship may occur in the two subregions. Specifically, it might be expected that more inconsistency in party identification is present in the Deep South states, where the national GOP has been extremely successful in recent 
presidential elections but the state Republican parties have had more difficulty, compared to the Peripheral South.

Table 6. Dual Partisan Identification in the 11 Southern States, by Subregion, Spring 1992 Southern Exposure Poll

\begin{tabular}{lcc}
\hline & Deep & Peripheral \\
& South & South \\
\hline Consistent GOP & $22.0 \%$ & $28.0 \%$ \\
Partially Consistent GOP & 2.9 & 2.0 \\
Split Republicans & 4.8 & 3.4 \\
Consistent Independents & 16.3 & 20.8 \\
Partially Consistent Independents & 2.9 & 3.6 \\
Split Independents & 9.6 & 9.6 \\
Consistent Democrats & 35.9 & 25.7 \\
Partially Consistent Democrats & 1.0 & 2.5 \\
Split Democrats & 4.8 & 4.5 \\
& $100.0 \%$ & $100.0 \%$ \\
& & $(\mathrm{n}=447)$ \\
\hline
\end{tabular}

*The Deep South states are defined as Alabama, Georgia, Louisiana, Mississippi, and South Carolina. The Peripheral South states are Arkansas, Florida, North Carolina, Tennessee, Texas, and Virginia.

While the levels of overall consistency in the two groups of states are essentially the same, there are stark differences in the bases of support the parties have in the subregions. These figures are shown in Table 6. While the Democratic Party maintains a strong plurality status in the Deep South states ( 35.9 percent of Deep South voters fit in the "consistent Democrat" category), the Republican Party has achieved parity with the Democratic Party in the Peripheral South. In fact, "consistent Republicans" slightly outnumber "consistent Democrats" in this subregion, with the percentage of "consistent Independents" close behind. Much has changed in these formerly one-party Peripheral South states. These conclusions about the levels of support for the parties in each subregion are accurate descriptions of the situation in both state and national politics. Contrary to what might be expected, little dual partisanship is found in either subregion.

\section{Explaining Dual Partisanship at the Elite Level in the South}

Charles Hadley's findings about the dual partisanship of party activists in Louisiana has been buttressed by surveys of party elites in other southern states. Dual partisanship questions were included in the 1991 state-by-state survey of party county committee activists in all the southern states. Democratic party activists were found to be less consistent in their party support than Republican activists, and, importantly, those Democratic activists who were not totally consistent in supporting their party at the two levels were almost all more 
supportive of their state party than of the national party (Clark and Lockerbie 1992). Amazingly, 17.4 percent of Arkansas' Democratic party activists admitted voting for George Bush in 1988 (Blair 1992).

These survey findings are reinforced by anecdotal evidence regarding southern Democratic party elites' tepidness in embracing their national party's candidates. For example, one veteran Democratic Arkansas state legislator, when asked if he would support his governor's 1992 candidacy for President, responded with less than enthusiastic support for his party at the national level: "Right now I have some reservations. I'm a Democrat and I usually support the Democratic candidate, but ..." (Rhodes 1991). The current president pro tem of the North Carolina state Senate, Marc Basnight, explained his votes against the Democratic party's presidential candidates in 1984 and 1988: "I'm a very loyal Democrat on the state level; always have been, and always will be. Nationally, I'm a business guy, and I saw things [in 1984 and 1988] that worried me a great deal. And, I ventured out to where I probably shouldn't have ventured to, but I did it."'

This dual partisanship among party elites in the South is especially intriguing, given the findings of this mass survey. Why would those most active in partisan politics in the region perceive, and in fact acknowledge within themselves, a dual partisanship that, at least according to these survey results, is not salient in the minds of the mass electorate?

The schema theory approach to political thinking may provide insight into this apparent contradiction. Advocates of this approach, which has its roots in social psychology, claim that it best integrates what has been learned about the subject and, moreover, better reflects how people actually think about politics. For instance, Conover and Feldman (1980) argue that Converse's (1964) "sociological" view of political thinking, which stresses the social origins of mass belief systems, and a "psychological" perspective that stresses the internal processes" power over political thinking (e.g., Lane 1962) are both "incomplete." Instead, "a political belief system may function in either a conceptually driven or event-driven fashion, and consequently may develop and change in response to both psychological and social factors." Thus, schema theory reflects the complexity of political thoughts.

As Feldman (1987) defines it, a schema is "a cognitive structure of 'organized prior knowledge, abstracted from experience with specific instances' that guides the processing of new information and retrieval of stored information." Schema theory is based on the assumption that persons are "cognitive misers," i.e., they have a limited capacity for dealing with all of the information that is in the world around them and must use cues and previously collected knowledge to make accurate and efficient judgements and decisions. Schema theory, then, both explains how people adjust to their cognitive limitations and how they actually structure the political information that they process.

Schemas develop through interactions with the environment and then, as "existing internal structures," influence the way in which new information is processed. This circular exchange between the individual and stimuli creates 
perceptions that are shaped both by the political information available from the environment and by internal cognitive limitations. Therefore, both external factors (like those emphasized by Converse) and internal factors (such as those emphasized by Lane) play a role in political thinking.

Party activists, for whom politics is more likely to be a part of their daily lives, tend to have better developed political schemas than nonactivists; i.e., they are more adept at processing political information (Lodge and Hamill 1986). Importantly, for the purposes of explaining the perceptions about dual partisanship that are present among the minds of elites but are not present among the mass electorate in the South, these activists are likely to be sensitive to political distinctions that are not picked up by the mass electorate. For instance, they might see patterns over series of elections in the campaign themes and strategies of the two parties' candidates at each level of the federal system that are not picked up by more casual political observers. It even might be argued that elites can be too sensitive to political information; Lodge and Hamill (1986) have pointed out that well developed schemas can introduce bias into the thinking of those who possess them. This may be the case with southern political elites' perceptions of party identification.

\section{Conclusion and Implications}

While some party activists in the region may perceive the existence of dual partisanship, the increased consistency in mass partisanship at the state and national levels during the last generation is an important finding from these survey results. In addition, vital differences in partisan balance exist for different age groups, sexes, and subregions in the southern electorate. These differences have important implications for the future of partisan politics in the region. Nevertheless, across all groups about three in four southerners are completely consistent in their party identifications at the two levels. Only a small percentage of southerners have "split" identities at the two levels, and there is no real difference in how these voters split; about the same percentage of voters shift away from each of the two basic state party identifications at the national level.

These findings are important in examining the question of why Republican success below the presidential level in the South has been elusive and inconsistent. If large percentages of dual partisanship, particularly "split Democrats," had been found, it might have been as a key ingredient in the absence of a top-to-bottom realignment in the region. Instead, to use the language of Alan Ehrenhalt (1991), the "customers" are not different at the two levels of southern politics. This leads one to believe that, in examining the question of why the Republican party has found such inconsistent success below the presidential level in the region, it is most appropriate to focus on the "product" end of the equation. What is different about the Democratic and Republican products being offered at the presidential and subpresidential levels, and why do these differences exist? 
The most obvious structural factors in southern politics that potentially obstruct Republican gains below the presidential level (in the form of offering better "products" in statewide elections) are Republican inability to construct an "opportunity ladder" that consistently provides candidates for statewide office of the same quality as Democratic candidates; other Democratic advantages in party organization in the eleven southern states, electoral rules such as holding elections for statewide offices in off-years, thus isolating these races from national campaigns, Democratic statewide candidates' ability to develop more appealing campaign strategies than "national Democrats," and differences in the use of the powers of incumbency by governors of the two parties. Such structural barriers certainly may serve as considerable obstacles to a "trickling down" of voting patterns in presidential politics to lower level races, but probably lack the stability they might have if they constantly were being reinforced by dual partisanship in the mass electorate of the South.

\section{NOTES}

'It may be significant to note that this 1985 poll preceded the election of the first GOP governor in Alabama in modern years.

${ }^{2}$ Figures derived from data in Sturrock (1990).

${ }^{3}$ Importantly, the poll was completed before the emergence of $\mathrm{H}$. Ross Perot as a player in the 1992 presidential campaign.

${ }^{4}$ The exact questions were as follows:

I'd like to ask you a few questions about your political party affiliations. First, I'd like to ask you about your party affiliation in state politics, then about your party affiliation in national politics.

A. Regardless of how you vote, when it comes to politics here in [name of state], do you usually think of yourself as a Republican, a Democrat, an Independent, or what?

IF DEMOCRAT or REPUBLICAN: Would you call yourself a strong [Dem. or Rep.] or a not very strong [Dem. or Rep.]?

IFINDEPENDENT: Do you usually think of yourself as closer to the Republican Party or closer to the Democratic Party?

B. Again, regardless of how you vote, when it comes to national politics, do you usually think of yourself as a Republican, a Democrat, an Independent, or what?

IF DEMOCRAT or REPUBLICAN: Would you call yourself a strong [Dem. or Rep.] or a not very strong [Dem. or Rep.]?

IF INDEPENDENT: Do you usually think of yourself as closer to the Republican Party or as closer to the Democratic Party?

${ }^{5}$ Respondents from five southern states (Alabama, Louisiana, Florida, North Carolina, and Texas) were included in the CSEP mass survey.

${ }^{6} \mathrm{Hadley}$ adapted this categorization technique from the work of Clarke, et al. (1979).

${ }^{7}$ The Deep South states are Alabama, Georgia, Louisiana, Mississippi, and South Carolina. Arkansas, Florida, North Carolina, Tennessee, Texas, and Virginia make up the 
Peripheral South.

${ }^{8}$ North Carolina Public Radio, 13 December 1992.

\section{REFERENCES}

Barth, Jay and John Haskell. 1990. Testing for Realigning Trends in State Treasurer and Attomey General Races in the South. Presented at the annual meeting of the Southern Political Science Association, Atlanta, GA.

Black, Earl and Merle Black. 1992. The Vital South: How Presidents Are Elected. Cambridge, MA: Harvard University Press.

1987. Politics and Society in the South. Cambridge, MA: Harvard University Press.

Blair, Diane D. 1992. Emerging Partisan Organizations in Arkansas. Presented at the 1992 Citadel Symposium on Southern Politics, Charleston, SC.

Burnham, Walter Dean. 1970. Critical Elections and the Mainsprings of American Politics. New York: Norton Press.

Clark, John A. and Brad Lockerbie. 1992. Split Partisanship Among Grassroots Party Activists. Presented at the 1992 Annual Meeting of the American Political Science Association.

Clarke, Harold D., et al. 1979. Political Change in Canada. Toronto: McGraw-Hill Ryerson, Ltd.

Conover, Pamela Johnston and Stanley Feldman. 1980. Belief System Organization in the American Electorate. In John Pierce and John L. Sullivan, eds., The Electorate Reconsidered. Beverly Hills, CA: Sage.

Converse, Philip E. 1966. On the Possibility of a Major Realignment in the South. In Angus Campbell, et al., Elections and the Political Order. New York: John Wiley.

. 1964. The Nature of Belief Systems in Mass Publics. In David Apter, ed., Ideology and Discontent. New York: Free Press.

Ehrenhalt, Alan. 1991. The United States of Ambition: Politicians, Power, and the Pursuit of Office. New York: Random House.

Feldman, Stanley. 1987. Public Opinion. In Samuel Long, ed., Annual Review of Political Science, Vol. 2. Norwood, NJ: Ablex Publishing Corporation.

Hadley, Charles D. 1985. Dual Partisanship Identification in the South. Journal of Politics 47: 254-268.

Key, V.O., Jr.. 1959. Secular Realignments and the Party System. Journal of Politics 21: 198-210.

Lane, Robert E. 1962. Political Ideology: Why the American Common Man Believes What He Does. New York: Free Press.

Lodge, Milton and Ruth Hamill. 1986. A Partisan Schema for Political Information Processing. American Political Science Review 80: 505-519.

New York Times. 5 November 1992. Portrait of the Electorate.

Pomper, Gerald. 1967. Classification of Presidential Elections. Journal of Politics 29: 535-566.

Rhodes, Larry. 1991. Broken Promise Would Be Forgiven, Lawmakers Say. Arkansas Democrat 16 August. 
Schreiber, E. M. 1971. 'Where the Ducks Are': Southern Strategy Versus Fourth Party. Public Opinion Quarterly 35, 157-167.

Stanley, Harold W. 1988. Southern Partisan Changes: Dealignment, Realignment or Both? Journal of Politics 50: 64-88.

Sturrock, David E. 1990.The Quiet Frontier: Recent Developments in Southern DownTicket Politics. Presented at the 1990 Citadel Symposium on Southern Politics, Charleston, SC.

Sundquist, James L. 1983. Dynamics of the Party System, rev. ed. Washington: Brookings Institution.

Thomas, James D. and William H. Stewart. 1988. Alabama Government and Politics. Lincoln, NE: University of Nebraska Press. 